\title{
Japan - Countervailing Duties on Dynamic Random Access Memories from Korea (DS 336 and Corr.1, adopted 17 December 2007)*
}

\author{
MEREDITH A. CROWLEY \\ Federal Reserve Bank of Chicago, 230 S. LaSalle St., Chicago, IL 60604 \\ Email: Crowley.meredith@gmail.com \\ D A VID PALMETER \\ Senior Counsel, Sidley Austin LLP, Washington, D.C.
}

\begin{abstract}
This article analyzes the decision of the WTO's Appellate Body in the dispute between Japan and Korea over Japan's imposition of countervailing duties on DRAMs imported from Korea. The legal analysis comments on the analysis of evidence, the lack of remand authority in the WTO system, and the meaning of a 'direct transfer of funds'. The economic analysis discusses several issues related to determining the magnitude of the benefit to a firm of a financial bailout and the appropriate duration of a countervailing duty to offset the injury caused by a non-recurrent subsidy. We offer legal and economic criticisms of the Appellate Body's conclusion regarding the relationship between subsidies and injury to the domestic import-competing industry. We conclude that the Appellate Body's decision weakens the requirement of a causal link between subsidies and injury and, consequently, may open the door to protectionist abuse of the Subsidies and Countervailing Measures Agreement.
\end{abstract}

\section{Introduction}

In 2001, Hynix Semiconductor, a computer-memory-chip producer located in Korea, teetered on the edge of bankruptcy. At this time, computer-memory-chip producers around the world were losing money as the worldwide production of computer memory outpaced its demand. Hynix was one of many firms around the world threatened with a merger or a breakup. However, Hynix was an important player in the Korean economy. In 2000, Hynix accounted for almost $4 \%$ of Korean exports. ${ }^{1}$

\footnotetext{
* The ideas and opinions expressed in this article are those of the authors and not necessarily those of the Federal Reserve Bank of Chicago or the Federal Reserve System. This paper was prepared for The American Law Institute project on the case law of the WTO. We thank Paola Conconi, Bernard Hoekman, Henrik Horn, Tom Prusa, and participants at the ALI conference held at the WTO on 17 June 2008 for helpful comments on an earlier draft.
}

1 Prusa (2008). 
In October 2001, the creditors of Hynix engaged in a bailout of the company. This bailout, or financial restructuring, involved two types of financial arrangements. The first type was a debt-for-equity swap. In the debt-for-equity swap, the many banks who held corporate bonds issued by Hynix agreed to exchange them for newly issued shares of stock in the company. The second type of financial arrangement was loan forbearance in which Hynix's creditors agreed to change the terms of loans made to Hynix. Loan forbearance generally involves a creditor either reducing the interest rates charged on loans or extending the time for repayment of loans. Although this is costly to creditors (relative to having the loan repaid under its original terms), creditors are often willing to do this for financially distressed firms or individuals if they think that this will maximize their return on a loan that has a strong chance of never being repaid.

Although the October 2001 restructuring placed Hynix on firmer financial ground in the short run, by December 2002 the financial condition of the company had again deteriorated to the point where a second bailout by Hynix's creditors was necessary to keep the firm solvent.

Subsequent to the Hynix bailouts, three WTO members - the United States, the European Communities, and Japan - alleged that the government of Korea had been involved in the Hynix bailouts in such a way that the bailouts constituted countervailable subsidies under the Subsidies and Countervailing Measures (SCM) Agreement. All three imposed countervailing duties on imports of DRAMs (dynamic random access memories) from Korea. Korea responded by challenging each under the Agreement on Subsidies and Countervailing Measures (SCM Agreement).

In Korea's challenge to Japan, the Panel accepted Japan's conclusion that the October 2001 bailout was a countervailable subsidy. However, the Panel found that no subsidy existed in the December 2002 bailout. Further, the Panel found that Japan erred in calculating the magnitude of the benefit of the subsidy. Japan appealed five of the Panel's substantive and methodological rulings and Korea appealed four, not all of them raising particularly important legal questions. The Appellate Body reversed the Panel on two of Japan's appeals, upholding the Panel on three, and upheld the Panel on all four issues appealed by Korea.

The three DRAMs cases involving Korea share some similarities, but there are unique questions raised in each case. Previous work (Francois and Palmeter, 2008 and Prusa, 2008) has addressed the US-DRAMS case. ${ }^{2}$ In this article, we discuss the legal and economic issues that we think were most important in the Japan-DRAMs case. Our analysis, at times, goes beyond a strict legal interpretation of the case under the current WTO agreement to ask whether some provisions of the current agreement yield the most desirable economic outcomes. 
Among the questions we address are: (1) Did the Hynix restructurings in October 2001 and December 2002 constitute a countervailable subsidy under the SCM?; (2) If the Hynix restructurings were countervailable subsidies, then what was the magnitude of the benefit to Hynix?; and (3) What types of effects must subsidies have on market competition in order to be countervailed under the SCM?

\section{Important issues of law}

This appears to be a dispute in which each Member appealed any issue that appeared remotely appealable. Consequently, some of the issues, while perhaps not trivial, are unlikely to be of lasting import. Four, however, raise important legal issues involving the analysis of evidence, the consequences of the Appellate Body's lack of remand authority, the meaning of 'direct transfer of funds', and the required causal connection between subsidies and material injury within the meaning of Article 15.5 of the Agreement.

\subsection{Analysis of evidence}

An issue in Japan-DRAMs, as in US-DRAMS (Francois and Palmeter, 2008), was whether Korea entrusted or directed private creditors to participate in the restructuring of Hynix, thereby providing a subsidy within the meaning of Article 1.1 of the Agreement. As in the US-DRAMS case, the Appellate Body disagreed with the methodology used by the Panel to evaluate evidence. In Japan-DRAMs, the Panel found that the October 2001 restructuring did involve entrustment or direction. However, it disagreed with the Japan investigating authority's (JIA) conclusion that the December 2002 restructuring also involved entrustment or direction. That restructuring paralleled the October 2001 restructuring with one difference. In 2002, Deutsche Bank issued a report to the creditors that, the Panel found, provided existing creditors with a proper financial basis for participating in the December 2002 restructuring. JIA's conclusion that the Deutsche Bank Report did not provide such a basis, the Panel held, was in error and, accordingly, found the participation of the creditors in 2002 to be commercially reasonable and, therefore, not entrusted or directed by the government of Korea.

The Appellate Body did not upset the Panel's substantive conclusion with regard to the Deutsche Bank Report, but found that this conclusion - by itself - was not necessarily enough to support the Panel's finding of no entrustment or direction. 'The JIA came to its finding on entrustment or direction based upon a consideration of the totality of the evidence before it', the Appellate Body said. 'It is not evident to us that the JIA accorded such decisive weight to the issue of commercial reasonableness as to render insignificant other evidence relating to [Korea's] intent to save Hynix and its intervention in the restructuring process' (para. 133). Accordingly, the Appellate Body held, the Panel should have considered whether 
the remaining evidence provided an objective basis for finding entrustment or direction. The Panel's failure to undertake such an examination amounted to a failure to apply the required standard of review.

The substantive legal point here is simple: when a decision is made on the totality of the evidence, the removal of one item of evidence does not necessarily negate the validity of the decision. That depends upon whether the remaining evidence can support the conclusion.

\subsection{Lack of remand authority}

Because the participants on appeal did not provide detailed evidence and argument on this aspect of the issue, the Appellate Body concluded that, having reversed the Panel, it could not itself apply the correct standard of review and complete the analysis. The effect was to deny Korea a decision on its claim.

Here Korea requested consultations in this dispute in March 2006. A year and nine months later, after going through the Panel and Appellate Body processes, Korea was still without a final ruling on its claim. The practical effect is to leave standing the decision of the JIA to impose countervailing duties on DRAMs from Korea based in part upon Japan's finding of entrustment or direction in the December 2002 restructuring. No decision was reached by either the Panel or the Appellate Body on whether the remaining evidence would or would not support the JIA's finding. In most legal systems, the appellate tribunal would have the authority to remand the case to the lower tribunal with instructions to address that question (Palmeter and Mavroidis, 2004: Section 6.06).

\section{3 'Direct transfer of funds'}

Korea argued that the debt-for-equity swaps and loan forbearance were not 'direct transfers of funds' within the meaning of SCM Article 1.1(a)(1)(i), and, therefore, none of them could constitute a subsidy. Korea argued that a direct transfer of funds could arise only when there is an incremental flow of funds to a recipient.

JIA's rejection of this argument was upheld by the Panel, which was affirmed by the Appellate Body. Korea's argument, the Appellate Body said, 'fails to encapsulate how financial transactions give rise to an alteration of obligations from which an accrual of financial resources results' (para. 250). The fact that the terms 'grants, loans, and equity infusions' are used in Article 1, and not 'modifications', does not mean that modifications of existing obligations cannot amount to a direct transfer of funds. 'Grants, loans, and equity infusions' are explicitly given as examples, not as an exhaustive list. Debt forgiveness, extensions of maturity dates, and interest-rate reductions improve the financial position of the borrower, the Appellate Body said, and therefore amount to a direct transfer of funds within the meaning of Article 1.

The Appellate Body, the Panel, and the JIA were correct: any other decision would unjustifiably elevate form over substance and eviscerate Article 1. 


\subsection{Causation of injury}

SCM Article 15.5 requires a demonstration 'that the subsidized imports are, through the effects of subsidies, causing injury within the meaning of this Agreement' (emphasis added). A footnote to the word 'effects' states: 'As set forth in paragraphs 2 and 4.' These paragraphs refer to the volume and price effects of subsidized imports, as measured by such indicia as the domestic industry's market share, profitability, and levels of employment. The Panel sustained JIA's finding of injury caused by subsidized imports, within the meaning of SCM Art. 15.5, and Korea appealed, arguing that the Panel 'effectively read the "through the effects of subsidy" language out of' the Article. The effects of subsidies must be distinguished from the effects of subsidized imports, Korea contended, because an increase in the volume of subsidized imports or the price at which they are sold may not have been caused by the subsidies.

The Appellate Body disagreed, and upheld the Panel. Korea's argument, the AB said, 'would imply additional inquiry by an investigating authority into two matters: first, the use to which the subsidies were put by the exporting company; and secondly, whether, absent the subsidy, the product would have been exported in the same volumes or at the same prices'. The AB concluded that Article 15 does not require two inquiries. The Appellate Body's conclusion weakens the causal link required between subsidies and countervailing duties, and allows protection to industries whose condition could be no different than it would be in the absence of subsidies. It is partially caused by the drafting of Article 15, which also refers to factors other than 'subsidized imports' that may be causing injury, implying that it is the imports per se, and not their subsidy, that must cause injury. The Appellate Body's grasping of this language and ignoring the full text, its context, and its object and purpose, however, does - as Korea argued-effectively rule the 'through the effects of subsidy' requirement out of the Agreement. The Appellate Body's contention that Korea's interpretation would require two separate investigations is not convincing. It ignores the way in which the burden of proof can shift during a legal proceeding.

A case before the investigating authorities of a WTO Member would begin with the complaining party establishing both the existence of a subsidy and injury as described in SCM Articles 15.2 and 15.4. In the absence of further evidence, the investigating authorities would be justified in finding a causal connection between the two. It would be the responsibility of the defending party to demonstrate that, even though a subsidy exists, and even though the domestic industry is experiencing injury, that injury is not caused by 'the effects of the subsidy' but by something else. If the defending party could not demonstrate this, the countervailing duty would be justified. If it succeeded in doing so, the burden simply would shift back to the complaining party to overcome that evidence. That is merely a continuation of the inquiry, not a separate inquiry. 
Consider, for example, a case in which the subsidy is $5 \%$ and the imports are underselling the domestic product by $50 \%$, and the domestic industry experiences injury. Suppose that in the absence of the subsidy, ceteris paribus, the imports would undersell the domestic product by $45 \%$. These facts would support an inference that any injury caused by the imports is not 'through the effects of the subsidy'. It might be possible, however, for the domestic industry to demonstrate that because of factors such as brand recognition and customer loyalty, an imported product must undersell it by more than $45 \%$ in order to be competitive. If this were established, the imports would not sell, and the domestic industry would not be injured, in the absence of the $5 \%$ subsidy. In such a case, the injury would be 'through the effects of the subsidy'.

Thus, the Appellate Body's stated fear of a required additional investigation if the 'through the effects of the subsidy' language is given its ordinary meaning is unwarranted. The routine shifting of the burden of coming forward with proof, requiring the party asserting the affirmative of a proposition to support it - claim, response, rebuttal, surrebuttal - will dispose of the issues in a single examination of 'all relevant evidence before the authorities' (Article 15.5).

\section{Important issues of economics}

In this dispute, a number of complaints were made about the economic analysis and the methodologies employed. The most important questions of economics related to calculating the magnitude of the benefit to Hynix; the effects of subsidies on market competition and the causation of injury; and the duration of countervailing duties for a non-recurring subsidy.

\subsection{The magnitude of the benefit of Hynix's financial restructuring}

In the Hynix case, a central question was how to value the Hynix bailout. If Hynix's creditors had simply forgiven a loan valued at $\$ 10$ million and asked for nothing in return, the benefit of the bailout to Hynix would have been $\$ 10$ million. However, the package consisted of a number of elements, the two most important being a debt-for-equity swap and new loan terms.

A variety of economic arguments were put forward both by Korea and Japan, but the most substantive questions were: (1) What is the appropriate perspective from which a government agency should evaluate a private agent's investment decision? (2) How should one calculate the value of a subsidy to a recipient when little information is available? (3)What constitutes a 'direct transfer of funds'?

Evaluating a private agent's investment decision: inside and outside investors In its initial countervailing duty investigation, Japan found that in October 2001, Hynix was in selective default on its loans and could not obtain additional funds on the commercial market. From this, Japan concluded that the participation of banks in the Hynix bailout was based on non-financial factors, presumably government pressure. 
Korea countered ${ }^{3}$ that an 'inside investor' might be willing to offer additional funds to an insolvent firm if he thinks that the additional funds will somehow enable him to minimize his losses. Korea argued that because Japan assessed the investment decisions of Hynix's creditors from an 'outside investor' perspective, Japan's assessment was fundamentally flawed. ${ }^{4}$

A basic concept in economics is that a rational investor does not make her investment decisions according to previous expenditures (i.e., 'sunk costs') on a project. ${ }^{5}$ Rather, at every point in time at which the rational investor must decide whether or not to continue funding a project, she assesses the expected return or future profitability of a project ignoring any and all previous outlays. If the discounted present value of a project is positive - that is, the discounted current and future benefits exceed the discounted current and future costs - then the rational investor should continue to provide funding. Otherwise, she should abandon the project.

Consider the following example. Suppose a man owns $100 \%$ of a financially distressed firm. The value of the firm, if it is rescued from financial distress, is $\$ 100$. The value, if it is not, is $\$ 0$. An investment of $\$ 10$ has a $50-50$ chance of saving the firm. Given these parameters, the expected total value of the firm is $\$ 40$ if the owner attempts to save it. ${ }^{6}$ Because the expected value of the firm, if the owner attempts to save it, is larger than the value of $\$ 0$ that will be realized if no effort is made to save the firm, the rational course of action for the owner is to undertake the risky investment of $\$ 10 .^{7}$

Suppose the owner tries to raise the $\$ 10$ he needs to try to save his company through an equity infusion from an outsider. Would the investment decision of an outsider differ from that of the inside investor in any economically meaningful way?

An outside investor would make the same rational decision to try to save the firm if prices are set efficiently. Because the expected value of the distressed firm is $\$ 40$, then a $25 \%$ stake in the firm is worth $\$ 10$. An equity infusion or financial transaction in which the owner gives the outside investor a $25 \%$ stake in the firm

3 Panel Report, Japan-DRAMs (Korea), paras. 4.3-4.8.

4 Conconi (2008) offers some additional explanations for why inside and outside investors might behave differently. She discusses recent research in behavioral and financial economics regarding how agents respond to sunk costs. This line of research suggests that irrational-seeming behavior does not necessarily provide proof of government intervention.

5 Sunk costs are distinct from fixed costs in economics. A sunk cost is a cost that has already been incurred and cannot be reversed. In contrast, a fixed cost, a cost that a firm must incur if it is to produce at all and that is independent of a firm's level of output over a wide range of possible levels, is relevant to assessing investment opportunities and a firm's value. See Grossman and Mavroidis (2003, 2005) for a thorough analysis of the economics of non-recurrent subsidies to cover fixed costs, such as technology, plants, or equipment.

6 Expected total value of firm $=($ value if saved $*$ probability success $)+($ value if sunk $*$ probability failure $)$ - cost to try to save $=(\$ 100 * 0.5)+(\$ 0 * 0.5)-\$ 10=\$ 40>0$.

7 To be precise, the owner owns a firm worth $\$ 40$. Thus, any transaction that leaves the owner with stuff (cash, assets, etc.) worth $\$ 40$ is rational. 
for $\$ 10$ and then uses the $\$ 10$ to try to save the firm would be rational for each party and would yield each party an expected profit of zero. ${ }^{8}$

In the Japan-DRAMs case, the Appellate Body was correct in concluding that the appropriate perspective from which the government should judge the investment decision is that of a rational investor. As the example presented above illustrates, rational inside investors and outside investors arrive at the same investment decisions when the values, risks, and costs are known to all parties.

However, in other future cases, it might be possible for a country to make an argument in favor of the use of an inside-investor standard for analyzing investment behavior. In such a case, the burden of proving that an inside-investor standard is warranted must fall upon the party that is challenging the countervailing duty.

For example, Korea could have made an argument that asymmetric information among market participants resulted in there being two types of potential investors in the Hynix bailout, fully informed inside investors and uninformed or partially informed outside investors. ${ }^{9}$ When informational asymmetries exist, the owner of an asset has a better understanding of the asset's true value than any potential buyer. In a market plagued by asymmetries in the information held by buyers and sellers, price discovery is difficult and market benchmarks which assume that all agents have full information may not be appropriate. Because Hynix was operating in a high-tech industry in which both the products and the production processes were undergoing constant innovation and improvement, one could have argued that it would be particularly difficult for an outside investor to figure out precisely what Hynix was really worth. If Hynix's product or production process was technologically superior to its competitors and the revelation of this information to the public would have been costly to Hynix because it would have assisted Hynix's competitors with technological catch-up, then the value of Hynix on commercial debt and equity markets would have been lower than Hynix's innate value. In this case, because an inside investor would have had access to proprietary information that was not available to the public, he would likely have been willing to invest additional funds in Hynix even if the commercial market would not have.

Although one can construct a hypothetical argument in favor of using an insideinvestor perspective in the face of a difficult information problem, the available details about Hynix's bailout suggest that it would have been extremely difficult for Korea to prove that a serious information problem existed in October 2001 and December 2002. ${ }^{10}$

8 The inside investor's profit from the transaction $=$ expected value of $100 \%$ of the failing firm $-(\mathrm{ex}-$ pected value for $75 \%$ stake owned by insider after equity infusion + payment for $25 \%$ stake) $=$ $\$ 40-\{(0.75 * \$ 40)+\$ 10\}=\$ 40-\{\$ 30+10\}=\$ 0$. The outside investor's profit = expected value of $25 \%$ stake - payment for $25 \%$ stake $=(0.25 * \$ 40)-\$ 10=\$ 0$.

9 This is the type of problem analyzed by George Akerlof (1970) in his seminal work on information problems in asset markets.

10 Because Micron Technology, Inc., an American DRAM producer with detailed knowledge of the industry offered \$3.4 billion for Hynix in early 2002, we can deduce that the minimum true value of Hynix 
In light of this analysis, how should we view the economic arguments of the $A B$ ? In throwing out the inside investor-outside investor argument made by Korea, the $\mathrm{AB}$ wrote:

We do not consider the distinction between the inside and outside investors to be helpful in order to determine the appropriate benchmark for calculating the amount of benefit under Articles 1.1(b) and 14 of the SCM Agreement... informational constraints do not alter the basic framework from which the analysis should proceed. We do not consider that there are different standards applicable to inside and outside investors. There is but one standard - the market standard - according to which rational investors act. ${ }^{11}$

The Appellate Body's economic logic was sound in this case; they correctly dismissed the use of an inside-investor standard for calculating the magnitude of the benefit to Hynix. Moreover, the various references to 'the market' in Article 14 of the SCM Agreement all seem to point to the use of a market standard as the default reference that any analysis should use.

However, the precise language used by the $\mathrm{AB}$ was unfortunate in its presumption that informational constraints do not change the way in which markets should be analyzed. Although there was no reason to modify the economic analysis because of informational constraints in this particular case, as a general rule informational constraints can play a critically important role in the functioning of markets. As such, future policy actions and dispute-settlement activities should pay heed to the role of information in the functioning of markets.

\section{Calculating the value of a subsidy to the recipient}

Since the Appellate Body ruling in the Canada-Aircraft case, ${ }^{12}$ WTO law has held that the benefit of a subsidy should be calculated according to the value to the recipient. As a question of economic analysis, debate can arise over the appropriate methodology for doing this. In the Japan-DRAMs case, this question conflated two distinct economic issues: (1) was Japan's methodology for calculating the benefit to Hynix reasonable and (2) why did a difference between the value to the recipient and the cost to the benefactor exist. Japan argued that, first, banks invested in Hynix for non-commercial reasons; second, that there was no available market benchmark against which Japan could precisely quantify the exact value of the benefit to Hynix; and, third, in this information vacuum, it was appropriate for Japan to value Hynix debt at its nominal face value and to value Hynix equity at zero value. Thus, from Japan's perspective, the value to Hynix of the

at that time was $\$ 3.4$ billion. In order for the Korean government to prove that Hynix was more valuable than this offer and equal in value to the bailout made by Hynix's investors in December 2002, the Korean government would have needed to provide detailed information about the proprietary technologies held by Hynix and its numerous competitors in order to show that Hynix was a considerably better investment than it appeared to be.

11 Appellate Body Report, Japan-DRAMs (Korea), para. 172.

12 Appellate Body Report, Canada-Aircraft. 
restructuring was the same as that of an outright grant equal to the nominal face value of the forgiven debt.

As a question of economics, the Panel's finding that Japan erroneously overstated the magnitude of the benefit of the October 2001 bailout to Hynix was correct. However, the Panel's reasoning was not. Specifically, the Panel wrote: 'we consider that such an approach erroneously overstates the amount of benefit conferred on the recipient, for it overlooks the perspective of the recipient, i.e., Hynix, which must dilute the ownership of existing shareholders in return' ${ }^{13}$

The Appellate Body tried to clarify that stock dilution and shareholder rights were not relevant by stating that: 'dilution of the rights of existing shareholders does not appear to be a relevant issue on the facts of this case'. ${ }^{14}$ Unfortunately, they may have inadvertently added confusion to the calculation of benefits in future cases by adding: 'the relationship between a company and its shareholders might be relevant for calculating the amount of benefit to the recipient' ${ }^{15}$

An economic analysis of the benefit to a firm of a subsidy must begin by clarifying why the benefit to the recipient differs from the cost to the benefactor. In the Hynix case, it seems likely that the benefit to Hynix of the bailout was equal to the costs of Hynix's creditors once we fully account for all of the costs and benefits to the creditors of participation in the bailout.

The benefit to Hynix's creditors of participating in the bailout likely combined two elements, the value of ownership shares in Hynix and a non-financial, difficult-to-quantify benefit of a good relationship with the Korean government. Thus, Japan's methodology, which valued the cost of Hynix's debt forgiveness at its nominal face value, likely overstated the benefit to Hynix because it failed to take into account that the creditors received a valuable benefit of improved Korean government relations as part of the bailout. Under this view, there is a clear economic rationale for using a methodology that relies on quantifying the benefit to the recipient and not the cost to the benefactor.

In light of this, how could Japan have constructed a reasonable measure of the benefit to Hynix of the bailout program?

There are different ways to determine the total value, or equity, of Hynix. One approach would have been to define the total value of Hynix, in October 2001, as the total value of Hynix's assets (equipment, plants, patents) less the total value of its debts. The complicating factor in this calculation is that, in October 2001, there was little expectation that Hynix would fully repay its debts. Consequently, the market price of a Hynix bond would have been significantly less than its nominal face value. An alternative method would have been to multiply the number of outstanding shares of Hynix stock by the market price of stock in

13 Panel Report, para. 7.313.

14 AB Report, para. 181.

15 Ibid. 
October 2001. The problem with both methodologies was that market prices of Hynix debt and equity were difficult to obtain because of Hynix's terrible financial condition.

Japan could have begun with a definition: the total equity of a firm equals its total assets less its total liabilities. Under financial distress, it might have been reasonable for Japan to assume that the total value of Hynix equity in October 2001 was zero. But this assumption would have required that Japan value Hynix's debt at a distressed price that equated the total value of Hynix's plants, equipment, patents, etc., with the total distressed value of Hynix's liabilities. In summary, if Japan had constructed a 'market value' or 'distressed value' of Hynix's forgiven debt under an assumption that Hynix's equity was zero, this 'distressed value' of forgiven debt would have been a reasonable measure of the magnitude of the benefit to Hynix of the bailout program.

\section{'Direct Transfer of Funds'}

In Section 2.3 we argued that the Appellate Body was correct in upholding the Panel's rejection of Korea's claim that Hynix's bailout was not a 'direct transfer of funds'.

The Panel made the correct determination ${ }^{\mathbf{1 6}}$ from an economic perspective in finding with Japan that both debt-for-equity swaps and loan modifications constitute 'direct transfers of funds'. Similarly, the Appellate Body's economic logic was correct in upholding the Panel's decision. Both transactions under debate clearly involved the transfer of value to Hynix through financial instruments. To treat them as something other than a 'direct transfer of funds' would have made an arbitrary distinction among different types of financial arrangements that would simply lead to the creation of complex financial transactions designed to circumvent the SCM.

\subsection{Causation of injury and the effects of subsidies on market competition}

In Section 2.4, we offered a legal criticism of the Appellate Body's conclusion regarding Korea's claim that the Panel read the 'through the effects of subsidies' language out of the SCM Agreement. As a question of law, the Appellate Body's language weakens the requirement of a causal link between subsidies and countervailing duties. This weakening of the causal link is highly undesirable from an economic perspective because it opens the door to protectionist abuse of the SCM Agreement.

As a legal issue, we argued that providing evidence of a causal link between subsidies and injury does not require a separate investigation, but can be brought forward as the burden of proof shifts between parties in an inquiry.

Moreover, as an economic issue, a widely accepted view of the SCM Agreement is that it exists to help neutralize the terms-of-trade effects (or relative-price effects)

16 Panel Report, paras. 7.439-7.446. 
of subsidies. This view holds that the entire point of the SCM Agreement is to allow countries to minimize negative price effects caused by a trading partner's subsidies. ${ }^{17}$ In this context, an economist would view the limits imposed by the injury test as arising directly from a subsidy's effect on prices in the importing country. If a subsidy has a large price-distorting effect, then it will produce measurable injury and may be countervailed. If it has little or no price-distorting effect, then injury would not exist and the subsidy would not be countervailable. ${ }^{18}$ Even within this framework, economists recognize that the mere presence or absence of injury is insufficient for determining the appropriate magnitude of a countervailing duty. The magnitude of a trade restriction used to offset the effect of a subsidy should be commensurate with the magnitude of the injury caused by the subsidy.

In the course of the hearing before the Appellate Body, Korea raised the point that subsidies can have effects not only on the prices and volumes of traded goods, but also on non-price attributes of a good such as quality. In Korea's view, if a subsidy improved product quality and, thus, through its improved quality, took sales away from the domestic industry, 'there would be no basis for findings that the imports, that happened to be subsidized, had caused injury "through the effects of subsidies", (para. 82).

In our view, this particular argument tries to create a false distinction between two intimately related attributes of a good, its price and quality. A subsidy could double the quality of a product (e.g., the processing speed of a DRAM) or reduce the price of the existing quality good by half. In either case, the result is the same; the consumer gets twice as much of the desired attribute for the same price through the effect of a subsidy.

This example highlights why even simple econometric models that can quantify the effects of a subsidy on prices and quality are useful in countervailing duty investigations. Although they are not required by the SCM Agreement, they can ensure that countervailing duties are calibrated to precisely offset the injurious effects of subsidies.

\subsection{The duration of countervailing duties for a non-recurring subsidy}

In the course of its 2003 investigation of Hynix, Japan amortized the nonrecurrent, lump-sum subsidy provided by Hynix's creditors in October 2001 over a five-year period, 2001-2005. The purpose of this calculation was to determine the magnitude of the benefit that the bailout provided to Hynix in 2003. Japan

17 See, for example, Bagwell and Staiger (2006).

18 Grossman and Mavroidis (2003) provide an excellent discussion of why the benefit of a subsidy is not necessarily a financial one, but occurs through a change in the economic environment that a 'but for' injury analysis will reveal. They conclude: 'A consistent interpretation of the SCM Agreement calls for a "but for" test for continuing injury from a non-recurring subsidy. The authorities in the importing country should periodically review whether its domestic producers of like products are suffering harm relative to what would be their economic condition but for the prior non-recurring subsidy.' 
imposed countervailing duties valued at roughly one-fifth of Hynix's non-recurrent subsidy in each year, 2003-2006.

Korea objected to the imposition of a countervailing duty in 2006 because, by Japan's own reasoning, the effect of the subsidy was exhausted in 2005.

Both the Panel and the $\mathrm{AB}$ made the correct economic determination in siding with Korea on this point. In general, the productive life of an asset (e.g., factory equipment) is industry-specific and, thus, the time period over which a lump-sum subsidy confers a benefit is determined by the asset's productive life. Logic dictates that if an asset's productive life is five years, then a countervailing duty to offset the effect of a subsidized asset should last no more than five years.

\section{Conclusions}

The Appellate Body's analysis of the question of whether or not the Hynix restructurings in October 2001 and December 2002 were countervailable subsidies was bifurcated into an existence determination and a magnitude-of-benefit determination. The first issue was a legal question of whether or not either restructuring constituted a subsidy. Specifically, did the Korean government 'entrust or direct' Hynix's creditors to participate in the bailouts? Although the analysis could have relied on an econometric analysis of the benefits in order to determine the existence of a subsidy, in bifurcating the analysis, the economic analysis and economic questions were deferred to the magnitude-of-benefit determination.

Both the Panel and the Appellate Body framed their analyses of the second question, regarding the magnitude of the benefit to Hynix from the bailout programs, as subordinate to the legal question of the existence of a subsidy.

The Appellate Body came to the correct conclusions on the economic questions in the Japan-DRAMs case. However, the Appellate Body's economic reasoning was not always correct. The AB's task in developing its economics analysis was complicated by the fact that the economic arguments presented by the parties and the Panel were sometimes incorrect and at other times were irrelevant. Both the Panel and the Appellate Body spent a great deal of time bogged down in hearing arguments that ultimately had no bearing on the case, but which were construed by the parties to be related to the economic criteria set out in the SCM Agreement.

\section{References}

Akerlof, George A. (1970), 'The Market for "Lemons”: Quality Uncertainty and the Market Mechanism', The Quarterly Journal of Economics, 84: 488-500.

Bagwell, Kyle and Robert W. Staiger (2006), 'Will International Rules on Subsidies Disrupt the World Trading System ?', The American Economic Review, 96: 877-895.

Conconi, Paola (2008), 'Comment on "Japan - Countervailing Duties on Dynamic Random Access Memories from Korea”, by Crowley and Palmeter', forthcoming in World Trade Review 2009:1, and in Henrik Horn and Petros C. Mavroidis (eds.), The American Law Institute - The WTO Case Law of 2006-2007: Legal and Economic Analysis, Cambridge: Cambridge University Press. 
François, Joseph F. and David Palmeter (January 2008), 'US - Countervailing Duty Investigation of DRAMS', World Trade Review, 7: 219-229.

Grossman, Gene M. and Petros C. Mavroidis (2003), 'United States - Imposition of Countervailing Duties on Certain Hot-Rolled Lead and Bismuth Carbon Steel Products Originating in the United Kingdom: Here Today, Gone Tomorrow? Privatization and the Injury Caused by Non-Recurring Subsidies', in Henrik Horn and Petros C. Mavroidis (eds.), The WTO Case Law of 2001 - The American Law Institute Reporters' Studies, Cambridge: Cambridge University Press, pp. 170-200.

Grossman, Gene M. and Petros C. Mavroidis (2005), 'United States-Countervailing Measures Concerning Certain Products from the European Communities: Recurring Misunderstanding of Non-Recurring Subsidies', in Henrik Horn and Petros C. Mavroidis (eds.), The WTO Case Law of 2002 - The American Law Institute Reporters' Studies, Cambridge: Cambridge University Press, pp. 78-87.

Palmeter, David and Petros C. Mavroidis (2004), Dispute Settlement in the World Trade Organization: Practice and Procedure, 2nd Edition, Cambridge: Cambridge University Press.

Prusa, Thomas J. (January 2008), 'Comment on "US - Countervailing Duty Investigation of DRAMS", by Francois and Palmeter', World Trade Review, 7: 231-234.

\section{Appendix: Table of cases}

\begin{tabular}{|c|c|}
\hline Short title & Full case title and citation \\
\hline Canada-Aircraft & $\begin{array}{l}\text { Appellate Body Report, Canada-Measures Affecting the Export of Civilian Aircraft, } \\
\text { WT/DS70/AB/R, adopted } 20 \text { August 1999, DSR 1999:III, } 1377\end{array}$ \\
\hline Japan-DRAMs & Appellate Body Report, Japan - Countervailing Duties on Dynamic Random Access \\
\hline (Korea) & Memories from Korea, WT/DS336/AB/R and Corr.1, adopted 17 December 2007 \\
\hline $\begin{array}{l}\text { Japan-DRAMs } \\
\text { (Korea) }\end{array}$ & $\begin{array}{l}\text { Panel Report, Japan-Countervailing Duties on Dynamic Random Access Memories } \\
\text { from Korea, WT/DS336/R, adopted } 17 \text { December 2007, as modified by Appellate } \\
\text { Body Report, WT/DS336/AB/R }\end{array}$ \\
\hline US-DRAMS & $\begin{array}{l}\text { Panel Report, United States - Anti-Dumping Duty on Dynamic Random Access } \\
\text { Memory Semiconductors (DRAMS) of One Megabit or Above from Korea, } \\
\text { WT/DS99/R, adopted } 19 \text { March 1999, DSR 1999:II, 521 }\end{array}$ \\
\hline
\end{tabular}

